\title{
Ultrasonography of the tongue movements for the /I/ sound and characterization by gender in children with typical and atypical speech development
}

\author{
Luciana da Silva Barberena ${ }^{1}$ \\ https://orcid.org/0000-0002-6014-2903 \\ Isadora Mayer Rosado² \\ https://orcid.org/0000-0002-1105-4915 \\ Denis Altieri de Oliveira Moraes ${ }^{3}$ \\ https://orcid.org/0000-0002-2059-5481 \\ Larissa Cristina Berti ${ }^{4}$ \\ https://orcid.org/0000-0002-4144-2804 \\ Márcia Keske-Soares ${ }^{5}$ \\ https://orcid.org/0000-0002-5678-8429
}

Universidade Federal de Santa Maria UFSM, Santa Maria, Rio Grande do Sul, Brasil.

Universidade Federal de Santa Maria UFSM, Programa de Pós-graduação em Distúrbios da Comunicação Humana, Santa Maria, Rio Grande do Sul, Brasil.

Universidade Federal de Santa Maria UFSM, Curso de Estatística, Santa Maria, Rio Grande do Sul, Brasil.

Universidade Estadual Paulista Júlio de Mesquita Filho - UNESP, Curso de Fonoaudiologia e Programa de Pósgraduação em Fonoaudiologia - UNESPMarília; Programa de Pós-graduação em Estudos Linguísticos, Campus São José do Rio Preto, São Paulo, São Paulo, Brasil.

Universidade Federal de Santa Maria UFSM, Curso de Fonoaudiologia e Programa de Pós-graduação em Distúrbios da Comunicação Humana, Santa Maria, Rio Grande do Sul, Brasil.

Study conducted at the Postgraduate Course in Human Communication Disorders, Federal University of Santa Maria-UFSM- Santa Maria, RS, Brazil.

Research support source: Higher Education Personnel Improvement Coordination - Capes and National Council for Scientific and Technological Development - CNPq.

Conflict of interests: Nonexistent

\section{(c) (i)}

Received on: October 11, 2018

Accept on: May 15, 2019

Corresponding address:

Luciana da Silva Barberena

Rua Tuiuti, 480, apto 201

CEP: 96015-660 - Santa Maria, Rio Grande do Sul, Brasil

Email: lucianabarberena@hotmail.com

\section{ABSTRACT}

Objective: to compare the articulatory gestures of the /// sound, characterized by gender variable, of children with typical and atypical speech development.

Methods: the sample was composed of 60 children, 30 with typical speech development and 30 with atypical speech development, aged between 4 years and 8 years and 11 months, of both genders, being the $/ / /$ sound acquired for all children. The articulatory data (ultrasound image of tongue movement) were collected from the recording of tri/polysyllabic words with the sound $/ /$, considering the maximum elevation of the tongue point analyzed through the Articulate Assistant Advanced (AAA) software. The mean tongue contours of typical and atypical children were compared to the gender variable in order to observe possible differences between these groups.

Results: there was a significant difference in the tongue gestures of typical and atypical children in the male gender. In females, there was less differentiation of the means of the tongue contours between the typical and atypical children.

Conclusion: the group of atypical male children presented less ability to refine the tongue gestures when compared to the typical ones of the same gender.

Keywords: Ultrasonography; Speech; Evaluation; Children; Speech therapy 


\section{INTRODUCTION}

For the child to acquire a sound according to the adult pattern, it is necessary that adequate neuropsychomotor development occur, with gradual refinement and coordination of the motor gesture ${ }^{1}$.

When there are changes in the sound system below the established age and in the absence of relevant cognitive, auditory, and/or psycho-affective changes, there is a Speech Sound Disorder (SSD) ${ }^{2,3}$. This designation has been used by Gestural Phonology ${ }^{4}$, a theory that understands speech production as a dynamic process that involves the coordination of articulators, allowing the characterization of tongue gestures according to trajectory and time ${ }^{5}$. According to some studies ${ }^{6,7}$, liquid consonants are complex sounds during speech acquisition and development. The production of the /// sound requires the production of double tongue gestures ${ }^{8}$, which justifies its complexity of acquisition.

According to Gestural Phonology, the child makes attempts to approximate the adult sound, but these approaches are not always audibly perceived, and ultrasound (USG) is important to demonstrate that the acquisition of sound contrast is present in the child's productions, with a gradual "refinement" of the articulatory gesture. This improvement of speech motor skills occurs even after the "end" of the acquisition period when articulatory gestures gradually become more stable in both temporal organization and magnitude ${ }^{9-11}$.

There are different population-based and local studies that aimed to verify the prevalence of SSD in relation to gender, in which there is a higher prevalence in males ${ }^{12-15}$. This research gathers significant data based on auditory-perceptual analysis, that is, there is no visualization of the articulatory gesture. Thus, the presence of "hidden contrasts" is not observed, which are auditory imperceptible phonic contrasts but detectable in the analysis of the images of tongue gestures through ultrasound ${ }^{16}$. The analysis of articulatory gestures by ultrasonography between children with typical speech development and those with SSD, considering the gender variable, can provide results on the evolution of gestural patterns.

The hypothesis of the study is that there are differences in the articulatory gestures of the tongue in the production of /// sound for each gender, even if the auditory perception is consistent with the adult target pattern.

The privileged aspects in this research are: a) to characterize the articulatory tongue gestures of the
// sound in children with typical and atypical speech development; b) to compare the articulatory gestures of the tongue between typical and atypical children of the same gender.

From these considerations, the interest of this research focuses on comparing the articulatory tongue gestures of the /// sound, characterized by the gender variable, of children with typical and atypical speech development.

\section{METHODS}

It is an experimental, descriptive, qualitative, and quantitative research. The research participants were children with adequate acquisition and development of speech/language, called typical children (TC) and children with alterations in the speech sound system, but with /// sound acquired, named and characterized in this study as atypical children. (AC).

All participants were selected for convenience, and they previously signed the Free and Informed Consent Form (FICF), according to the rules of the Research Ethics Committee of the Federal University of Santa (UFSM), approved under protocol No. 442,786, according to Resolutionnumber 466/12. Language/ speech, hearing, and ultrasound images evaluations were performed in a speech therapy center of a higher education institution.

To constitute the groups, all subjects were submitted to the following evaluations: articulatory examination, orofacial motricity, and neurovegetative functions (MBGR Protocol) ${ }^{17}$, sequencing and narration of facts ${ }^{18}$, silent hearing screening for frequencies from $500 \mathrm{~Hz}$ to $600 \mathrm{~Hz}, 20 \mathrm{~dB}$ (Interacoustic Screening Audiometer, portable audiometer model AS208) and Computerized Phonological Assessment Instrument (INFONO) ${ }^{19}$. For each child, two 45-minute sessions were used to perform these initial evaluations, always performed by the same evaluator throughout the sample selection process.

After the initial evaluations, the following criteria were considered for inclusion in this research: hearing within normal limits in both ears, structures, and functions of the stomatognathic system without alterations, members of the Brazilian Portuguese (BP) monolingual speaker family. The AC and TC were monolingual BP speakers, did not receive previous speech therapy or at the time of the beginning of the research, had hearing within normal limits in both ears, no complaints of chronic otitis media or at the time of research, expressive language development and age-appropriate 
understanding, with no learning-related complaints, and attend kindergarten, preschool or early grades. The AC presented different alterations in the speech sound system, but without compromising the /// sound. The TC showed the appropriate sound system for the age presented.

After selecting the participants according to the inclusion and exclusion criteria, for this study, two groups were constituted:

Group 1 - Group of Atypical Male and Female Children (GCA): 30 atypical children, 17 males, and 13 females, aged between 4 years and 8 years and 11 months. Male children had a mean age of 6 years and 3 months and female children 5 years and 7 months. GCA children presented different severities of SSD, characterized by the Percentage of Correct Consonants - Revised (PCC-R) 20.

Group 2 - Group of Typical Male and Female Children (GCT): 30 children with typical speech development, 17 male and 13 females, aged 4 years to 8 years and 11 months. Male children had a mean age of 6 years and 4 months and female children 5 years and 8 months. Thus, GCTA children were matched for gender and age in relation to group 1 (GCA).

For both groups, tongue ultrasound (USG) images were recorded during the speech. USG evaluations were performed individually for approximately 30 minutes in a single session. Each participant sat in a chair, in an acoustic booth, feet flat on the floor, upright speaker with microphone (Shure - SM48) positioned at mouth level, ultrasound probe (model 65C10EA endocavitary transducer) stabilized by the head stabilizer (Articulate Instruments Ltda.) and fixed externally below the mandible on the floor of the mouth. The probe used a transducer gel, which enabled the capture and visualization of the tongue contour images, using a frequency of $5.0 \mathrm{MHz}$.

The sagittal plane/Mode B was chosen for image analysis because it allows the visualization of the tongue from the root to the tip. Images were captured, recorded, and analyzed using Articulate Assistant Advanced (AAA) ${ }^{21}$ software.

For this study, three trisyllabic or polysyllabic words with the /I/ sound in tonic syllable were selected in different following vowel contexts, following vowel contexts of /a/, /i/ e /u/, being respectively, /sa.'la. da/ (SLA), /fa.'li.da/ (FLI) and /ka.be.'lu.du/ (CLU). Participants were instructed to speak the same sentence with these words. Each participant produced a total of three words presented separately in figure form on the computer screen and repeated six times each. The child should enter it in the phrase vehicle: "speak again" in the order shown in Figure 1. Thus, a total of 18 productions of each word per subject were obtained, making a total of 1080 productions for all participants (GCA and GCT).

After recording the images in the $A A A$ software, the outline of each participant's tongue was traced at each repetition in the image, referring to the maximum elevation of the anterior tongue area in the /I/ sound (frame). The sounds were identified by speech spectrography, simultaneous analysis between audio and video, properly synchronized by the software feature.

After selecting the frame, the same fan angle was chosen for all participants $\left(120^{\circ}\right.$, available inthe DP6600 ultrasound software itself). The fan has 42 radii projecting over the image. The radii that reach the image of the tongue contour are constituted by values (points of intersection), which correspond to the distances (in $\mathrm{mm}$ ) from the beginning of each radius at the base of the fan to the curve of the tongue.

Thus, valid points, that is, those that intercepted each tongue curve at each repetition for all participants, were copied from the software workspace to a spreadsheet containing 42 columns (numbered 0 to 41). However, it is noteworthy that only the valid points (100\% agreement) were completed for each participant, in the repetition for each word. Two spreadsheets were created in the Excel program, referring to the participants by group: comparing GCA and GCT in males and GCA and GCT in females.

After the spreadsheets were created, the data from each group were exported to the $\mathrm{R}$ statistical tool $(R$ Core Team, 2015). In the $R$ environment, we calculated the mean values of tongue contours in the repetitions of each word for each group (male AC and TC and female $A C$ and $T C$ ) and the respective confidence intervals around each of the mean values. The intervals were obtained with $95 \%$ confidence around each of the midpoints of the tongue curves (splines) and represent the minimum and maximum allowable variations for each tongue gesture.

After this step, the regions with significant differences ( $p$-value <0.05) between AC and TC for each gender were also verified by analyzing the 95\% confidence interval for the mean difference between the tongue contours. The regions that presented significant differences between the tongue gestures produced by the groups were those that did not contain the horizontal 
line referring to the zero value. In this context, when one of the range limits, the minimum or maximum, for a given spline exceeds the line representing the null difference hypothesis, it is said that in that region, there is a significant difference between the tongue gestures produced by each group.

In the classification of gestures, the descriptors proposed by Gestural Phonology (FonGest) were used, specifying the variables of the tract, which correspond to the constriction actions of the vocal tract organs and their reference with the articulators involved ${ }^{22,23}$. In the classification of gestures, there was also consensus among three speech therapists with experience in the speech area. The following are the tract variables considered for the qualitative descriptions of the articulatory gestures involved in the production of ///:

1) Tongue tip constriction site (TTCL).

2) Tongue tip constriction degree (TTCD).
3) Orientation of the oral constrictor.

4) Tongue body constriction location (TBCL).

5) Tongue body constriction degree (TBCD).

In the description corresponding to the /// sound were considered: tip of the tongue as an articulator and respective location of anterior constriction, being the orientation of the apicolaminal or alveolar articulator. Regarding the degree of constriction of the articulators, the descriptive tip of the open tongue (referring to the approximators) and narrow was selected as descriptor. Besides location and degree of constriction, we considered the number of gestures involved and whether or not they belonged to the same oral subsystem.

Figure 1 presents the words with /// considering the different vowel contexts following the vowels /a/, /i/ and $/ \mathrm{u} /$.

\begin{tabular}{|c|c|c|c|}
\hline Word & Abbreviation & Sound & Vowel context \\
\hline [sa'lada] & (SLA) & $/ / /$ & $/ \mathrm{a} /$ \\
\hline [fa'lida] & (FLI) & $/ /$ & $/ \mathrm{i} /$ \\
\hline [kabe'ludu] & $(\mathrm{CLU})$ & $/ \mathrm{l} /$ & $\mathrm{u} /$ \\
\hline
\end{tabular}

Figure 1. Words with $/ / /$, considering the different vowel contexts

\section{RESULTS}

In this study, we compared the average language contours between GCA and GCT in males and also between GCA and GCT in females to observe quantitative differences in tongue gestures for each gender.
Next, Figures 2, 3, and 4 show the mean tongue contours comparing GCA and GCT according to gender. All graphs followed the same criteria mentioned, and the intervals around the midlines, with $95 \%$ confidence, were calculated. 


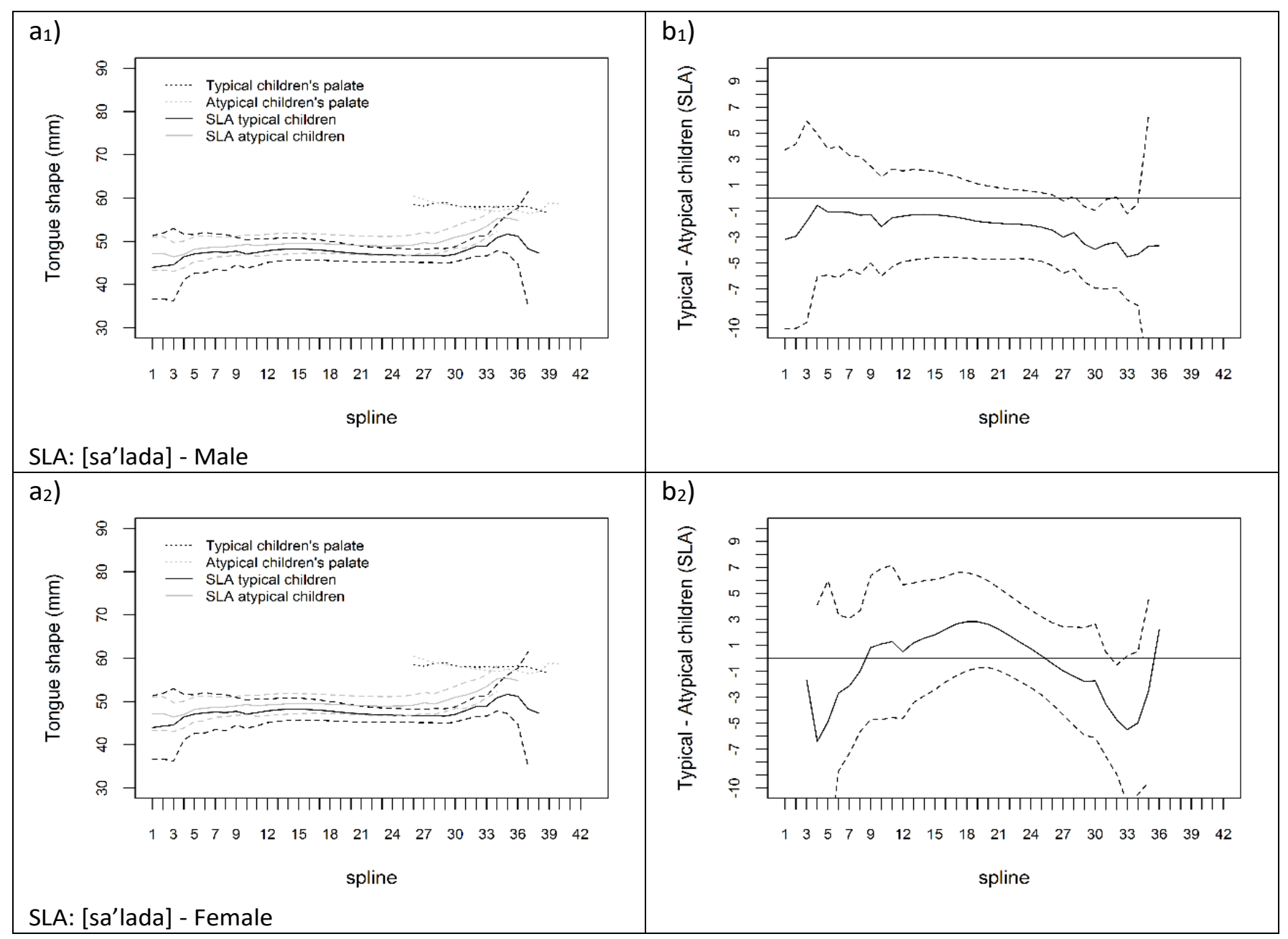

Figure 2. a) Confidence intervals for the mean language contours in /// respectively in the word /sa'lada/ (SLA) between GCT and GCA in males and females; b) Confidence interval for the difference in language curves between GCT and GCA in males and females for each segment in the respective word 


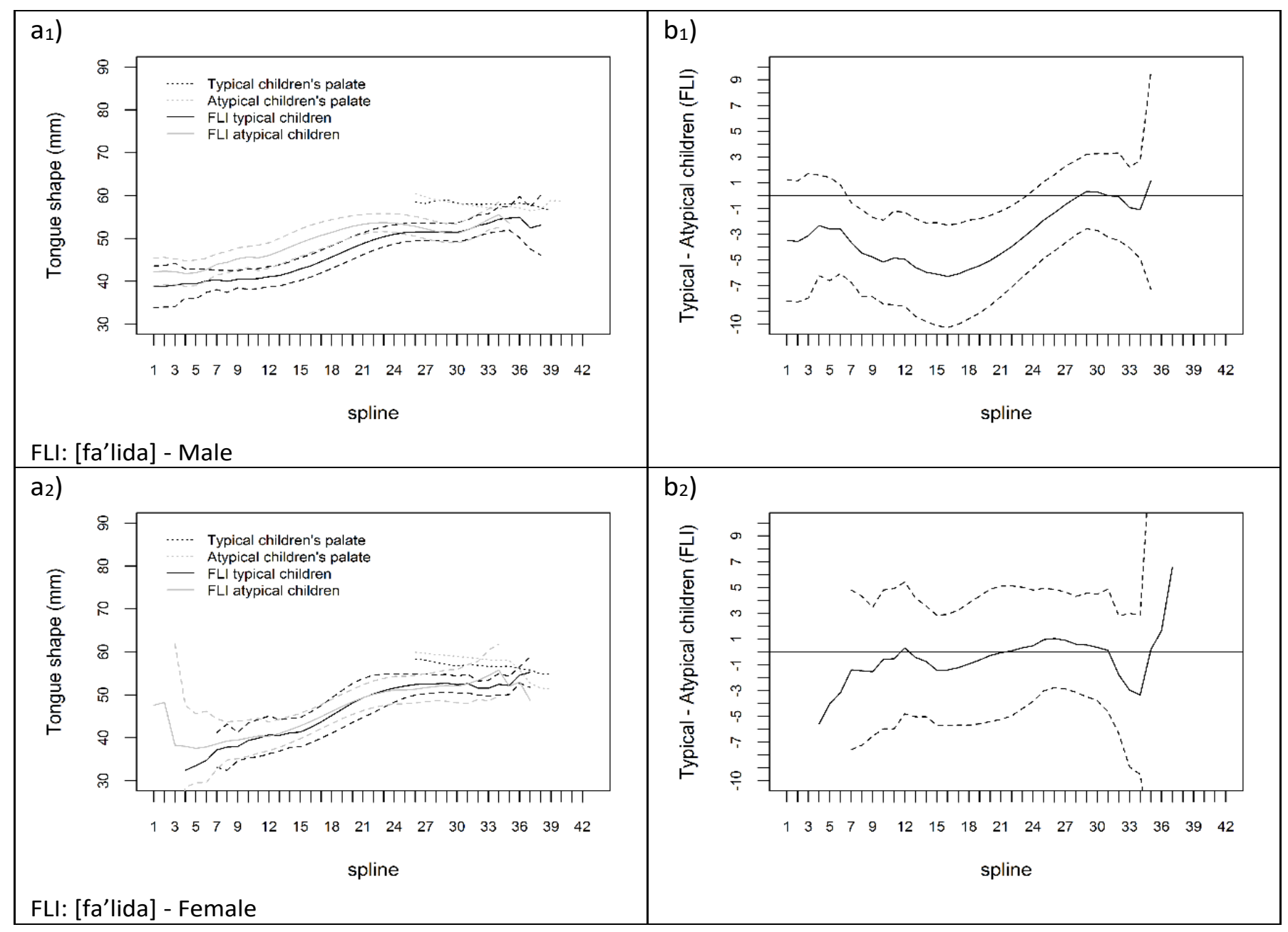

Figure 3. a) Confidence intervals for the mean language contours in [l] in the word [fa'lida] (FLI) between GCT and GCA in males and females; b) Confidence interval for the difference in language curves between GCT and GCA in males and females for each segment in the respective word. 


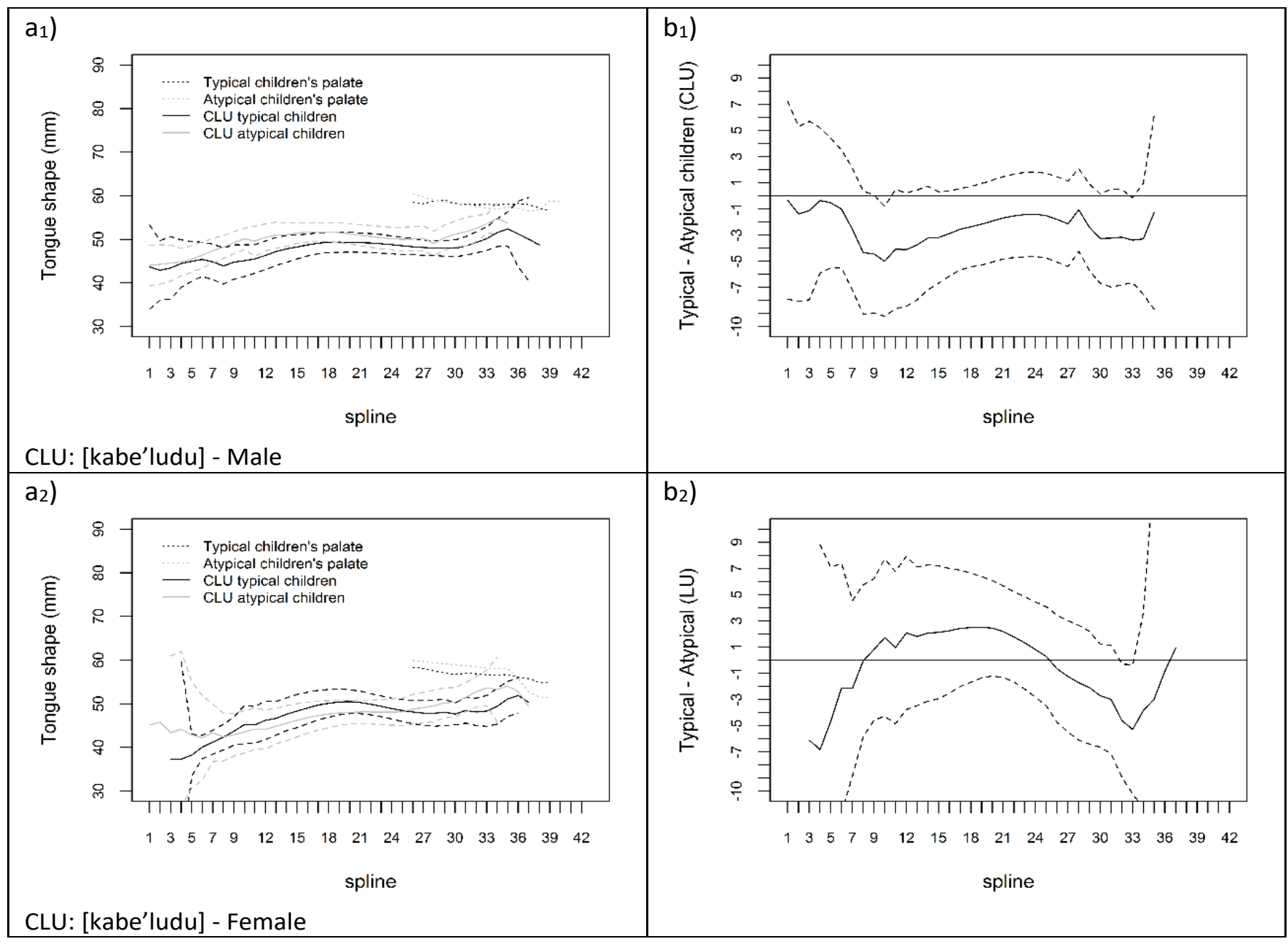

Figure 4. A1) Confidence intervals for the mean language contours in [I] respectively in the word [kabe'ludu] (CLU) between GCT and GCA in males and females; b) Confidence interval for the difference in language curves between GCT and GCA in males and females for each segment in the respective word.

In the word /sa'lada/ (SLA), that is, in the /I/ sound followed by the vowel context of /a/, there was a significant difference in the mean tongue contours in the tip region, both between male GCT and GCA and female GCT and GCA (Figure 2). This occurred although the significant range of midpoints on the tip of the tongue was larger between GCT and GCA in males.

In the word [fa'lida] (FLI), that is, in the /// sound followed by the vowel context of $/ \mathrm{i}$, there was a statistically significant difference for the mean tongue contours in the body region of the tongue when compared to male GCT and GCA. Between female GCT and GCA there was no statistically significant difference in any range of the tongue midpoints for this context (Figure 3).

In the word [kabe'ludu] (CLU), that is, in the /I/ sound followed by the vowel context of $/ \mathrm{u} /$, there was a significant difference in the mean contours of the tongue between tip and root between male GCT and GCA, while between female GCT and GCA there was difference only in the tip of the tongue region (figure 4). It is important to highlight that this word is polysyllabic, unlike the others, because it is a longer word, it requires more memory, information processing, and elaboration of the articulatory motor gesture.

\section{DISCUSSION}

The sonographic analysis of the tongue movements allowed to compare the articulatory gestures between typical and atypical children of the same gender. Between male GCT and GCA, there was a statistically significant difference in the mean tongue contours for all vowel contexts following the /// sound, while between female GCT and GCA, there was no difference in the following vowel context of /i/ for the /// sound. 
These results allowed us to state that atypical boys differ significantly from typical boys regarding tongue gestures in the production of the /// sound, and these differences are observed in several regions of tongue, tip, body or tip and root simultaneously, depending on the next vowel context presented. In females, for the /I/ sound, considering the next vowel context of /i/, no significant differences were observed in the mean tongue contours. In the vowel contexts /a/ and /u/ following the /// sound, these differences occurred only in the tip region of the tongue. Thus, for males, between GCT and GCA, there is greater differentiation in articulatory gestures involved in the production of the /// sound.

Articulatory gestures reveal variations dependent on the vowel context presented, as observed in another study for BP in typical speakers ${ }^{24}$. Phonetic detail processes are modeled as a result of variation in gestural parameters, or in the coordination between gestures ${ }^{25}$. The gesture occurs on the edge of certain borders, allowing the lexicalization of a different standardization in its realization, which elegantly models the linguistic change ${ }^{26}$.

For all vowel contexts following the /I/ sound, a smaller gestural magnitude was also observed when comparing male GCT and GCA compared to female GCT and GCA. Studies using the USG of tongue movements in atypical speakers mainly observed two types of gestural change: reduction in the magnitude of individual gestures and increase in gesture overlap ${ }^{27,28}$.

The number of boys with SSD is higher than the number of girls. In addition to linguistic alterations being more common in males, there are also different uses of repair strategy (called "phonological process" for Natural Phonology Theory)between genders ${ }^{13}$. The qualitative differences observed when comparing male GCT and GCA in relation to female GCT and GCA may also be justified as to the chronology of neuronal myelination, being earlier in girls in language-related areas, which may explain superiority in the development of language skills ${ }^{29}$. This fact is probably justified because boys present a slower development, being more susceptible to the influence of the environment or other factors on language development ${ }^{30}$.

Population-based research, or with representative samples of school-age children, found that speech delay, speech-language disorders, and phonological disorders are approximately 1.5 times more prevalent in boys than girls ${ }^{14,15}$. Other studies also indicated that speech disorders are more frequent in male children ${ }^{12,31-33}$.

A research verified the prevalence of phonological disorders in children aged four to six years attending public schools in a city, with the aim of verifying if these disorders varied according to age, gender, and socioeconomic class, and concluded that there was a high prevalence of phonological disorders in males, unlike what was observed when analyzing the age range ${ }^{12}$, however, there are no studies to prove the relationship between phonological disorders and predominance in males $29,30,34,35$.

In this study, between GCT and GCA in males, there were differences in gestural magnitude and mean tongue contours linked to the vowel context following the /// sound when observing comparisons between GCT and GCA in females. Among female GCT and GCA, in addition to greater gestural magnitude, there was a greater approximation of the average tongue contours for all studied vowel contexts, which leads to the hypothesis that atypical girls present a greater refinement of articulatory gestures than atypical boys.

\section{CONCLUSION}

Quali-quantitative analysis of tongue gestures by ultrasound images revealed that male GCA has less ability to refine double tongue gestures when compared to GCT of the same gender. Thus, a greater ability to refine articulatory gestures is observed when comparing female GCT and GCA. In this research, differences in the mean tongue contours were influenced by the gender variable.

\section{ACKNOWLEDGMENTS}

To the National Council for Scientific and Technological Development - CNPq for resources through Universal Notice 14/2013 - Process 483722/2013-8.

To the Coordenação de Aperfeiçoamento de Pessoal de Nível Superior - CAPES.

\section{REFERENCES}

1. Meyer PG. Tongue lip and jaw differentiation and its relationship to orofacial myofunctional treatment. Int J Orofacial Myology. 2000;26(1):44-52.

2. Carlino FC, Del Prette A, Abramides DVM. Assessing speech intelligibility level of children with phonological disorders: implications in social skills. Rev. CEFAC. 2013;15(1):10-1. 
3. Bonini JB, Bertagnolli APC, Freitas GP, BlancoDutra AP, Keske-Soares M. Efficacy of words favoring with fricative $/ 3 /$ in the phonological therapy. Disturb. Comun. 2014;26(2):396-404.

4. Albano EC. Uma introdução à dinâmica em fonologia. Revista Abralin. 2012;2(1):1-30.

5. Casero KTB, Brum-de-Paula M, Gonçalves FG. A consoante lateral palatal: análise acústica e articulatória à luz da Fonologia Gestual. ReVEL. 2016;14(27):79-114.

6. Gonçalves GF, Keske-Soares M, Checalin MA. Estudo do papel do contexto linguístico no tratamento do desvio fonológico. Rev.soc.bras. fonoaudiol. 2010;15(1):96-102.

7. Lamprecht RR. Aquisição fonológica do Português: perfil de desenvolvimento e subsídios para terapia. Porto Alegre: Artmed, 2004.

8. Gick B, Bacsfalv P, Bernhardt BM, Stolara S, Wilson I. A motor differentiation model for liquid substitutions: english $/ r /$ variants in normal and disordered acquisition. J. Acoust. Soc. Am. 2008;16(1):1-9.

9. Berti LC, Marino VCC. Contraste fônico encoberto entre /t/ e / $/ \mathrm{k} /$ : um estudo de caso de normalidade e de transtorno fonológico. Rev. CEFAC. 2011;13(2):97-110.

10. Cristofolini C, Seara IS. Características acústicas de consoantes plosivas e fricativas produzidas por crianças de 6 e 12 anos: período de refinamento articulatório? Verba Volant. 2012;3(1):55-71.

11. Freitas MC. $O$ gesto fônico na aquisição "desviante": movimentos entre a produção e a percepção [tese]. Campinas (SP): Universidade Estadual de Campinas, Instituto de Estudos da Linguagem; 2012.

12. Cavalheiro LG. A prevalência do desvio fonológico em crianças de 4 a 6 anos de escolas públicas municipais de Salvador-BA. Rev. Soc. Bras. Fonoaudiol. 2008;13(4):415.

13. Golembiouski GR, Dassie-Leite AP, Oliveira JP, Bagarollo MF. Characterization and follow-up of children with phonological disorder. Rev. CEFAC. 2014;16(1):318-27.

14. Matida AH, Camacho LAB. Pesquisa avaliativa e epidemiologia: movimentos e síntese no processo de avaliação de programas de saúde. Cad. Saude Publica. 2004;20(1):37-47.

15. Shriberg LD, Tomblin JB, McSweeny JL. Prevalence of speech delay in 6-year old children and comorbidity with language impairment. J. Speech Hear. Res.1999;42(6):1461-81.

16. Berti LC. Contrastes e contrastes encobertos na produção da fala de crianças. Pró-Fono R. Atual. Cient. 2010;22(4):531-6.

17. Genaro KF, Berretin-Felix G, Rehder MIBC, Marchesan IQ. Avaliação miofuncional orofacial protocolo MBGR. Rev. CEFAC. 2009;11(2):237-55.

18. Vidor-Souza D, Mota HB, Santos RM. A consciência fonoarticulatória em crianças com desvio fonológico. Rev. CEFAC. 2011;13(2):196-204.

19. Ceron MI. Instrumento de Avaliação Fonológica (INFONO): desenvolvimento e estudos psicométricos [Tese]. Santa Maria (RS): Universidade Federal de Santa Maria; 2015.

20. Shriberg ID, Austin D, Lewis BA, McSweeny JL, Wilson DL. The speech disorders classification system (SDCS): extensions and lifespan reference data. J. Speech Hear. Res.1997;40(4):723-40.

21. Articulate Instruments, LTD. Articulate Assistant User Guide: Version: 2.11. Edinburgh, UK: Articulate Instruments Ltda., 2010.

22. Browman CP, Goldstein L. Articulatory phonology: an overview. Phonetica. 1992;49(3-4):155-80.

23. Goldstein L, Fowler C. Articulatory phonology: a phonology for public language use. In: Meyer A, Schiller $N$ (orgs). Phonetic and phonology in language comprehension and production: differences and similarities. New York: Mountoun; 2003. p. 159-207.

24. Albano EC. O gesto e suas bordas: esboço de fonologia acústico-articulatória do português brasileiro. Campinas: Mercado de Letras; 2001.

25. Costa L. Modelamento teórico de processos variáveis em modelos dinâmicos de fala: possibilidades de representação do rotacismo no âmbito da fonologia gestual. Letras. 2012;28(1):387-404.

26. 26 Barberena LS, Keske-Soares M, Berti LC. Description of the articulatory gestures concerned in the production of the sounds $/ \mathrm{r} /$ and $/ \mathrm{I} /$. Audiol Commun Res. 2014;19(4):338-44.

27. Melo RM, Mota HB, Mezzomo CL, Brasil BC. Production and discrimination of voicing contrast of stops in cases of phonological disorder. Rev. CEFAC. 2015;17(Supl1):135-44.

28. Berti LC. Investigação ultrassonográfica dos erros de fala infantil à luz da Fonologia Gestual. In: Ferreira-Gonçalves G, Brum-de-Paula M (eds). Dinâmica dos movimentos articulatórios: sons, 
gestos e imagens. Pelotas: Editora UFPel, 2013. p. 127-44.

29. Indrusiak CS, Rockenbach SP. Prevalence of phonological deviations in children - 4 to 6 years old - from a kindergarten school in Canoas-RS. Rev. CEFAC. 2012;14(5):943-51.

30. Patah LK, Takiuchi N. Prevalência das alterações fonológicas uso dos processos fonológicos em escolares aos 7 anos. Rev. CEFAC. 2008;10(2):158-67.

31. Matumoto S, Mishima SM, Pinto IC. Saúde coletiva: um desafio para a enfermagem. Cad. Saude Publica. 2001;17(1):233-41.

32. 32 Santos GG, Melo PDF, Diniz JMG, Teixeira GPB. A importância do diagnóstico diferencial das alterações de fala: enfoque fonológico. J Bras Fonoaudiol. 2003;4(16):186-92.

33. Wertzner HF, Oliveira MMF. Semelhanças entre os Sujeitos com Distúrbio Fonológico. Pró-Fono R Atual Cientif. 2002;14(2):143-52.

34. Barros PML, Oliveira PN. Perfil dos pacientes atendidos no setor de fonoaudiologia de um serviço público de recife-PE. Rev. CEFAC. 2010;12(1):128-33.

35. César AM, Maksud SS. Caracterização da demanda de fonoaudiologia no serviço público municipal de Ribeirão das Neves - MG. Rev. CEFAC. 2007; 9(1):133-8. 